\title{
Salinity controls phytoplankton response to nutrient enrichment in the Great Salt Lake, Utah, USA
}

\author{
Amy M. Marcarelli, Wayne A. Wurtsbaugh, and Olivia Griset
}

\begin{abstract}
To examine how salinity and nutrient supply interact to control phytoplankton community composition, nutrient limitation, and dinitrogen $\left(\mathrm{N}_{2}\right)$ fixation rates in the Great Salt Lake (Utah, USA), we conducted a series of bioassay experiments with plankton from both Gilbert Bay, where salinities are near $160 \mathrm{~g} \cdot \mathrm{L}^{-1}$, and Farmington Bay, where salinities range from 10 to $90 \mathrm{~g} \cdot \mathrm{L}^{-1}$. Six-day nutrient addition bioassay experiments showed that the extant phytoplankton communities in both bays were limited by nitrogen $(\mathrm{N})$. However, in 28 - to 30-day factorial bioassay experiments in which both salinities and nutrient supply were manipulated, phosphorus stimulated chlorophyll $a$ as much as $500 \%$ when salinities were less than $70 \mathrm{~g} \cdot \mathrm{L}^{-1}$ and $\mathrm{N}_{2}$-fixing cyanobacteria were present. At salinities greater than $70 \mathrm{~g} \cdot \mathrm{L}^{-1}$, or with additions of combined $\mathrm{N}, \mathrm{N}_{2}$ fixation ceased. When $\mathrm{N}_{2}$-fixing cyanobacteria were absent, the plankton community was routinely N-limited regardless of salinity. The results of these experiments suggest that nutrient limitation of phytoplankton communities may change depending on salinity levels, because salinity controls whether $\mathrm{N}_{2}$-fixing cyanobacteria will be present in the phytoplankton community. Therefore, both salinity and nutrient supply must be considered when making water quality decisions for hypersaline systems such as the Great Salt Lake.
\end{abstract}

Résumé : Afin d'examiner comment la salinité et l'apport des nutriments contrôlent la composition de la communauté phytoplanctonique, la limitation par les nutriments et la fixation de diazote $\left(\mathrm{N}_{2}\right)$ dans le Grand Lac Salé (Utah, É-U.), nous avons mené une série de bioessais avec du plancton provenant de la baie Gilbert où les salinités s'approchent de $160 \mathrm{~g} \cdot \mathrm{L}^{-1}$ et de la baie Farmington où les salinités varient de $10-90 \mathrm{~g} \cdot \mathrm{L}^{-1}$. Des bioessais d'addition de nutriments pendant 6 jours montrent que les communautés actuelles de phytoplancton dans les deux baies sont limitées par l'azote (N). Cependant, dans des bioessais factoriels de 28-30 jours, dans lesquels à la fois la salinité et l'apport de nutriments sont manipulés, le phosphore stimule la chlorophylle $a$ par autant que $500 \%$, lorsque les salinités sont inférieures à $70 \mathrm{~g} \cdot \mathrm{L}^{-1}$ et qu'il y a des cyanobactéries fixatrices de $\mathrm{N}_{2}$ présentes. Aux salinités supérieures à $70 \mathrm{~g} \cdot \mathrm{L}^{-1}$ ou après l'addition de $\mathrm{N}$ combiné, la fixation de $\mathrm{N}_{2}$ cesse. Lorsque les cyanobactéries fixatrices de $\mathrm{N}_{2}$ sont absentes, la communauté planctonique est généralement limitée par $\mathrm{N}$, quelle que soit la salinité. Les résultats de ces expériences indiquent que la limitation des communautés phytoplanctoniques peut changer en fonction des niveaux de salinité, parce que la salinité contrôle la présence des bactéries fixatrices de $\mathrm{N}_{2}$ dans la communauté phytoplanctonique. C'est pourquoi on doit tenir compte à la fois de la salinité et de l'apport de nutriments lorsque l'on prend des décisions sur la qualité de l'eau dans les systèmes hypersalés tels que le Grand Lac Salé.

[Traduit par la Rédaction]

\section{Introduction}

Nitrogen $(\mathrm{N})$ is believed to control primary production in estuaries, coastal oceans (Paerl 1996), and most saline lakes (Javor 1989), whereas phytoplankton growth in fresh waters is thought to be more frequently limited by phosphorus $(\mathrm{P})$. However, many bioassays and whole-lake experiments have shown that $\mathrm{N}$ is limiting in lakes and streams as frequently as P (Elser et al. 1990; Francoeur 2001). Schindler (1977) argued that $\mathrm{N}$ should never limit production in lakes because dinitrogen $\left(\mathrm{N}_{2}\right)$ fixing cyanobacteria should be able to make up $\mathrm{N}$ deficits so that $\mathrm{P}$ becomes the limiting nutrient. Consequently, the question of $\mathrm{N}$ versus $\mathrm{P}$ limitation can be restated to ask what factor(s) limit $\mathrm{N}_{2}$ fixation in aquatic systems (Vitousek and Howarth 1991). Despite its importance, the factors that limit $\mathrm{N}_{2}$ fixation in both fresh and saline waters are poorly understood (Vitousek et al. 2002). In some saline systems, iron or molybdenum supplies (Howarth and Cole 1985; Evans and Prepas 1997) or zooplankton grazing coupled with low cyanobacterial growth rates (Marino et al. 2002) may be important, but it is unclear how broadly applicable these control mechanisms are. Salinity and $\mathrm{P}$ concentrations

Received 5 December 2005. Accepted 21 July 2006. Published on the NRC Research Press Web site at http://cjfas.nrc.ca on 26 September 2006.

J19031

A.M. Marcarelli, ${ }^{1,2}$ W.A. Wurtsbaugh, and O. Griset. ${ }^{3}$ Department of Aquatic, Watershed and Earth Resources / Ecology Center, Utah State University, Logan, UT 84321-5210, USA.

${ }^{1}$ Corresponding author (e-mail: amy.marcarelli@gmail.com).

${ }^{2}$ Present address: Center for Ecological Research and Department of Biological Sciences, Idaho State University, Pocatello, ID 83209-8007, USA.

${ }^{3}$ Present address: College of Education and Human Development, University of Southern Maine, Gorham, ME 04038, USA. 
are important control mechanisms on cyanobacterial growth, toxin production, and $\mathrm{N}_{2}$ fixation in the Baltic Sea and elsewhere (Lehtimäki et al. 1997). Interactions between these different factors may be important for controlling $\mathrm{N}_{2}$ fixation and cyanobacterial abundance in hypersaline systems such as the Great Salt Lake (Utah, USA).

Previous bioassays have indicated that plankton in the main basin of the Great Salt Lake are N-limited (e.g., Stephens and Gillespie 1976; Wurtsbaugh 1988), but the factor(s) controlling $\mathrm{N}_{2}$ fixation, and thus perpetuating $\mathrm{N}$ limitation, are not understood. In the Baltic Sea, Lehtimäki et al. (1997) found that the same factors (salinity, temperature, light flux, and phosphate concentration) favored both growth and $\mathrm{N}_{2}$ fixation by one cyanobacterium species. Salinity controls on growth and $\mathrm{N}_{2}$ fixation by cyanobacteria have been reported by others (Fernandes et al. 1993; Pinckney et al. 1995; but see Moisander et al. 2002), and some argue that increasing the sulfate $\left(\mathrm{SO}_{4}{ }^{2-}\right)$ content of the water inhibits molybdenum (Mo) uptake and, consequently, $\mathrm{N}_{2}$ fixation by cyanobacteria (Howarth and Cole 1985; Marino et al. 2002). However, Wurtsbaugh (1988) found that lowering the ratio of $\mathrm{SO}_{4}{ }^{2-}$ to Mo did not stimulate planktonic growth or $\mathrm{N}_{2}$ fixation in the Great Salt Lake. Evans and Prepas (1997) argue that high salinities (or alkalinities) inhibit iron uptake and thus restrict $\mathrm{N}_{2}$ fixation. Recently, Mills et al. (2004) performed bioassay experiments indicating that low iron and $\mathrm{P}$ supplies simultaneously limit $\mathrm{N}_{2}$ fixation in the ocean. Despite these advances, the factor(s) controlling plankton growth and $\mathrm{N}_{2}$ fixation in hypersaline systems remain elusive.

The Great Salt Lake experiences variable salinity both spatially and temporally as a result of human-constructed causeways and seasonally fluctuating freshwater inputs. Variable salinities, coupled with heavy nutrient loading into one of the bays, provided an opportunity to study how salinity and nutrient supply interact to control phytoplankton nutrient limitation. We conducted laboratory experiments to determine whether $\mathrm{N}$ or $\mathrm{P}$ control phytoplankton growth and $\mathrm{N}_{2}$ fixation at a variety of salinities found in the Great Salt Lake. The goal of these experiments was to determine whether nutrient limitation of phytoplankton production changes at different salinities and, therefore, which nutrients should be the focus of management to control eutrophication in the Great Salt Lake.

\section{Materials and methods}

\section{Study area}

The Great Salt Lake is a $5180 \mathrm{~km}^{2}$ closed-basin lake in Utah, USA (Fig. 1), and during our study, the mean lake depth was near $5 \mathrm{~m}$. Because of its shallow morphometry, the size of the lake can increase or decrease markedly with climatic fluctuations. The lake has been highly impacted by the construction of causeways that divide the system into three large bays. Gunnison Bay $\left(2520 \mathrm{~km}^{2}\right)$, located in the northwest area of the lake (Fig. 1), has salt concentrations between 280 and $300 \mathrm{~g} \cdot \mathrm{L}^{-1}$. Gilbert Bay $\left(2400 \mathrm{~km}^{2}\right)$, in the central portion of the lake, has salinities typically between 120 and $180 \mathrm{~g} \cdot \mathrm{L}^{-1}$ and supports a thriving brine shrimp population. Farmington Bay $\left(260 \mathrm{~km}^{2}\right)$ is very shallow and the mean depth was $<1 \mathrm{~m}$ during our study. It is bordered on its eastern and southeastern shores by the greater metropolitan
Fig. 1. Map of the Great Salt Lake (Utah, USA; see inset) showing the location of the major bays. This study was conducted in Farmington Bay (salinity 10-100 $\mathrm{g} \cdot \mathrm{L}^{-1}$ ) and Gilbert Bay (salinity 150-170 g. $\mathrm{L}^{-1}$ ). Automobile and railroad causeways separate Farmington Bay and Gunnison Bay, respectively, from Gilbert Bay. Breaches in the west ends of each causeway allow limited bidirectional exchanges of water between the bays. Hatched area indicates the greater Salt Lake City population area. WTP identifies the locations of wastewater treatment plants that discharge directly into Farmington Bay.

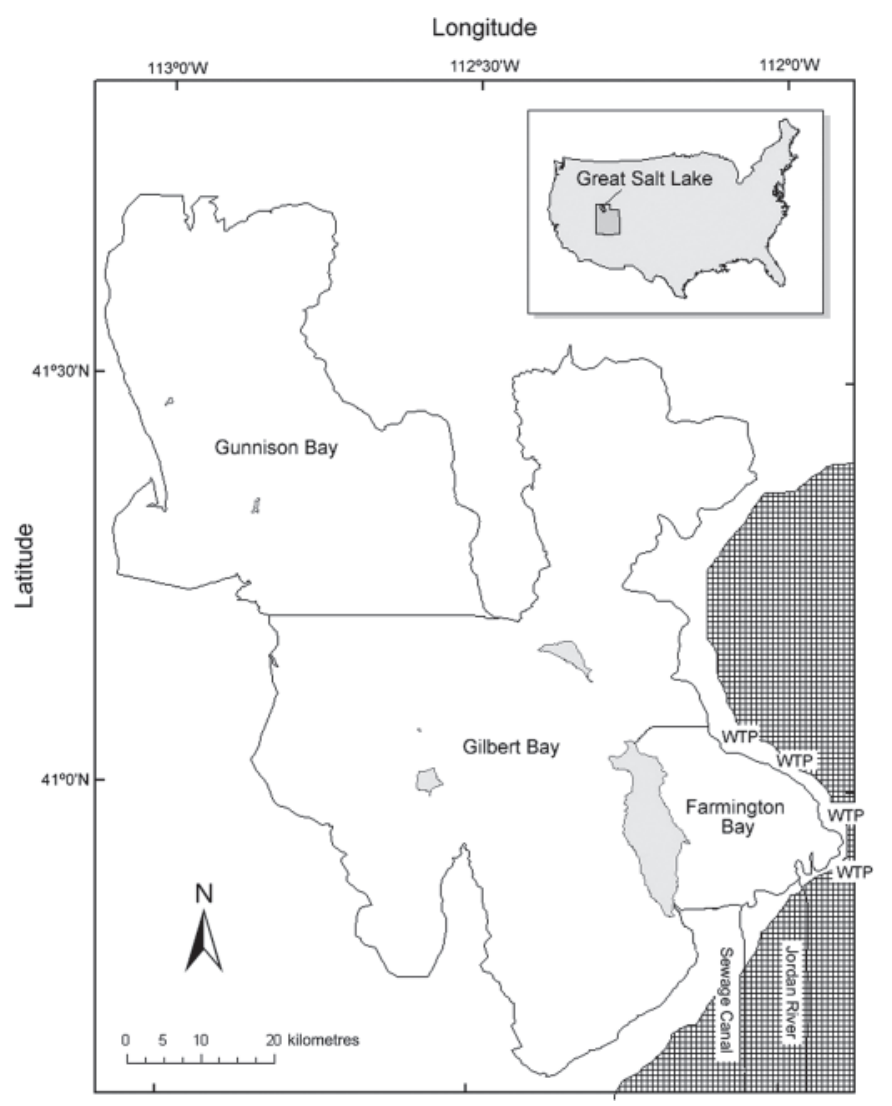

area of Salt Lake City. Farmington Bay receives a large portion of the fresh water flowing into Great Salt Lake via the Jordan River and sewage canals and therefore also receives a large portion of the nutrient loading to the lake. Wetlands at the southern end of the bay intercept and process an undetermined portion of the nutrients, but nutrient loading rates to the bay remain high. Phytoplankton chlorophyll $a$ levels in the bay usually exceed $100 \mu \mathrm{g} \cdot \mathrm{L}^{-1}$ and sometimes exceed $500 \mu \mathrm{g} \cdot \mathrm{L}^{-1}$. Secchi depth transparencies are normally near $0.2 \mathrm{~m}$. Salinity in Farmington Bay is highly variable, ranging from 5 to $100 \mathrm{~g} \cdot \mathrm{L}^{-1}$ depending on annual climate variations and lake elevation. The phytoplankton community in the Great Salt Lake is highly variable, depending on ambient salinities. At salinities between 5 and $50 \mathrm{~g} \cdot \mathrm{L}^{-1}$, the phytoplankton community is sometimes dominated by the $\mathrm{N}_{2}$-fixing cyanobacteria Nodularia spumigena. At higher salinities, the phytoplankton community is a mix of diatom and green algal species, most notably Dunaliella viridis (Carter 1971; Rushforth and Felix 1982; Stephens 1990). 


\section{Simple bioassay design}

A series of four simple bioassays was conducted to evaluate the extant nutrient status of the phytoplankton communities (Table 1). Water was collected either from the central region of Farmington Bay or from its northern shore in November 2003 when low water levels prevented boat access. Additionally, water was collected in Gilbert Bay on 29 August 2003 to compare nutrient limitation between the two bays of differing salinity. Water was collected with an $8 \mathrm{~L}$ horizontal Van Dorn bottle from $0.5 \mathrm{~m}$ depth and transported to the laboratory in $10 \mathrm{~L}$ polyethylene containers.

In the laboratory, macrozooplankton were removed by filtering through $153 \mu \mathrm{m}$ netting, and twelve $800 \mathrm{~mL}$ aliquots of water were randomly distributed into $900 \mathrm{~mL}$ glass jars with plastic lids. Jars were randomly assigned to four treatments with three replicates each: control $(\mathrm{C}),+\operatorname{nitrogen}(\mathrm{N})$, + phosphorus $(\mathrm{P})$, and + nitrogen + phosphorus (NP). Concentrations added to the treatments were $100 \mu \mathrm{mol} \cdot \mathrm{L}^{-1} \mathrm{~N}$ (as $\mathrm{NH}_{4} \mathrm{NO}_{3}$ ) and $6.5 \mu \mathrm{mol} \cdot \mathrm{L}^{-1} \mathrm{P}\left(\right.$ as $\left.\mathrm{Na}_{2} \mathrm{HPO}_{4}\right)$. Jars were then placed randomly in a temperature-controlled incubation room at $20{ }^{\circ} \mathrm{C}$, with light intensities of approximately $150 \mu \mathrm{mol}$ photons $\cdot \mathrm{s}^{-1} \cdot \mathrm{m}^{-2}$ and an $18 \mathrm{~h}$ light $-6 \mathrm{~h}$ dark photoperiod. Experiments lasted 6 days. Jars were agitated twice daily and re-randomized once daily to ensure even irradiance. Each jar was sampled for $\mathrm{N}_{2}$ fixation and chlorophyll $a$ after 3 and 6 days to examine phytoplankton responses to enrichment. Phytoplankton community composition was sampled only after 6 days.

\section{Factorial bioassay design}

We conducted four factorial bioassays in which nutrient and salinity levels were manipulated simultaneously (Table 1). Water was collected as above from the same sites. Salinities were manipulated in the source water from a low of $10 \mathrm{~g} \cdot \mathrm{L}^{-1}$, where cyanobacteria thrive, to $130 \mathrm{~g} \cdot \mathrm{L}^{-1}$, where we hypothesized that cyanobacteria, and therefore $\mathrm{N}_{2}$ fixation, would be absent (Table 1). To change salinities, an aliquot of source water was diluted with either deionized water or saline water (made with $\mathrm{NaCl}$ and $\mathrm{MgSO}_{4}$ in a 7.8:1 ratio in deionized water) to provide the desired salinities. The same aliquot volume of source water was used in all the salinity treatments of each experiment to ensure that the same initial amount of phytoplankton biomass was present in each nutrientsalinity treatment. These volumes varied between experiments depending on the salinity of the source water, which ranged from 15 to $170 \mathrm{~g} \cdot \mathrm{L}^{-1}$ (Table 1). Because these salinities varied widely, the proportion of source water placed into each jar also varied widely to achieve the target salinities, i.e., much less $170 \mathrm{~g} \cdot \mathrm{L}^{-1}$ source water needed to be used than $50 \mathrm{~g} \cdot \mathrm{L}^{-1}$ source water, if our maximum target salinity was $110 \mathrm{~g} \cdot \mathrm{L}^{-1}$. In all experiments, the water was filtered in the laboratory through $153 \mu \mathrm{m}$ netting to remove macrozooplankton, and the aliquots were placed in $900 \mathrm{~mL}$ glass jars. Jars were randomly assigned to salinity treatments, and the aliquots were diluted to $800 \mathrm{~mL}$ using deionized water or saline water to reach the desired end salinity. Salinity was measured after mixing with a refractometer. Additionally, $2.3 \mathrm{~mL}$ of supplementary inocula water from low-salinity sites in Great Salt Lake and surrounding wetlands and from a high-salinity site in Gilbert Bay was added to each jar to insure that a variety of phytoplankton with different salinity

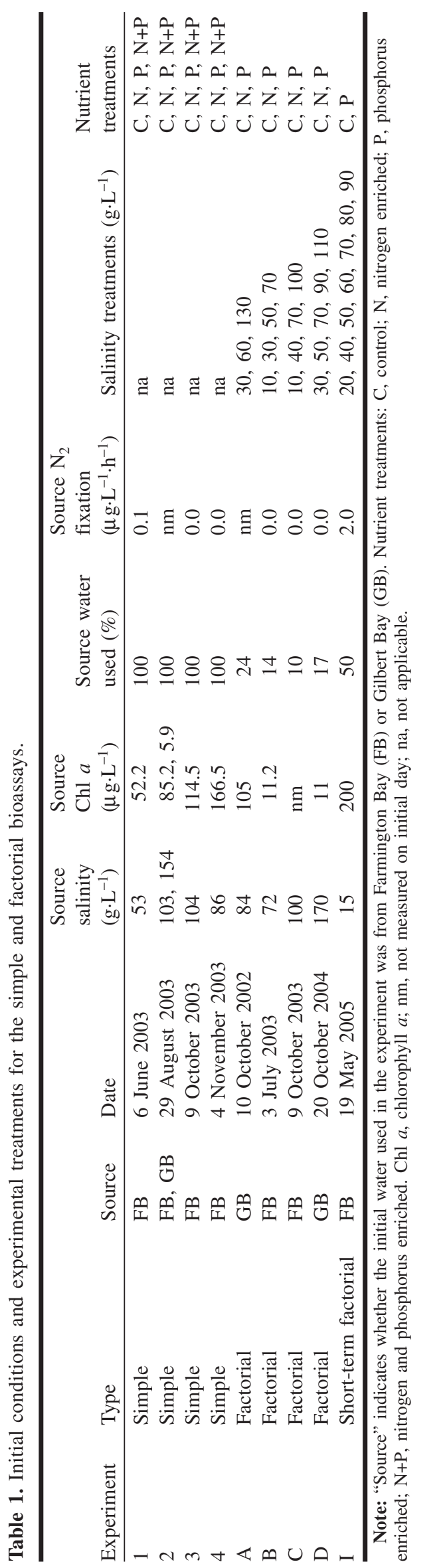

(C) 2006 NRC Canada 
tolerances were present at the start of the experiment. The jars within each salinity treatment were randomly assigned to three nutrient treatments: control $(\mathrm{C}),+$ nitrogen $(\mathrm{N})$, and + phosphorus $(\mathrm{P})$. Each salinity-nutrient combination had three replicates. Jars were enriched with nutrients, incubated, and agitated as described for the simple experiments. The four factorial experiments lasted 28-30 days and were sampled approximately every 7 days for $\mathrm{N}_{2}$ fixation and chlorophyll a. Phytoplankton community composition samples were collected on the final day of the experiment.

A final short-term factorial bioassay experiment (experiment I) was conducted in May 2005, when a large bloom of $N$. spumigena was present in Farmington Bay. The goal of this experiment was to look at salinity tolerance of $\mathrm{N}_{2}$ fixers present in the bay at that time. We chose to use a large number of salinity treatments for this experiment to allow a finer determination of the salinity at which $\mathrm{N}_{2}$ fixation ceased (Table 1). Because of the larger number of salinity treatments, we reduced the nutrient treatments to only a control and $\mathrm{P}$ enrichment and used only two replicates per salinitynutrient combination. Experiment I lasted 6 days and was sampled on days 1,3 , and 6 for chlorophyll $a$ and $\mathrm{N}_{2}$ fixation. This experiment was terminated after 6 days because visual observations indicated that the phytoplankton community had changed drastically by day 6 (color change from green to brown; senescence visually obvious).

\section{Sample analysis}

On sampling days, $50 \mathrm{~mL}$ aliquots of water were collected from each sample jar, placed in a $62 \mathrm{~mL}$ glass serum vial, and sealed with a septum for $\mathrm{N}_{2}$-fixation analysis. $\mathrm{N}_{2}$ fixation was measured using an acetylene reduction assay (Stewart et al. 1967; Flett et al. 1976). Once in the serum vial, assay samples and standard vials with deionized water were injected with $4 \mathrm{~mL}$ of acetylene, agitated for $1 \mathrm{~min}$ to evenly mix gas between the water and vapor stages, and incubated for $2 \mathrm{~h}$ in the incubation chamber in which the bioassay was conducted. The standard vials were also injected with known concentrations of ethylene so that a standard curve could be constructed. At the end of the incubation, vials were again agitated and gas samples were collected in cleaned, re-evacuated $3 \mathrm{~mL}$ Vacutainers ${ }^{\circledR}$. Ethylene and acetylene in each sample were measured within 2 months using a SRI 8610 gas chromatograph (SRI Instruments, Torrance, Calif.) with a Poropak T column (Waters Associates, Milford, Mass.) and a flame ionization detector. Ethylene concentration was converted to amount of $\mathrm{N}_{2}$ gas fixed using an assumed 4:1 molar ratio (Postgate 1998).

An index of phytoplankton biomass was estimated using chlorophyll $a$ analysis. An aliquot was removed from the serum vial after termination of the acetylene reduction assay and filtered through a $25 \mathrm{~mm}$ Millipore AP 40 glass fiber filter with a nominal pore size of $1.0 \mu \mathrm{m}$. The filter was wrapped in foil and immediately frozen to prevent sample degradation. Within 30 days of sample collection, filters were extracted in 95\% ethanol, and chlorophyll $a$ concentration was measured fluorometrically using a nonacidification technique with a Turner 10-AU fluorometer (Turner Designs, Sunnyvale, Calif.; Welschmeyer 1994).

Phytoplankton were collected from one replicate of each treatment at the beginning and end of each experiment.
Approximately $40 \mathrm{~mL}$ of sample was preserved with $3 \%$ Bouin's solution (80\% formaldehyde, saturated with picric acid; $20 \%$ glacial acetic acid) or with $3 \%$ formalin. Phytoplankton cell density was determined by settling in Utermöhl chambers and counting on an inverted Olympus microscope at 1000× (Wetzel and Likens 2000). Phytoplankton were identified to the lowest taxonomic group possible (usually genus or species) using Felix and Rushforth (1979). Length and width measurements were made on 10 individuals of each taxa, and biovolume was calculated using equations from Hillebrand et al. (1999).

\section{Data analysis}

Results were analyzed both as simple treatment responses and as responses relative to controls. Percent of control responses were calculated using the following equation:

$$
\begin{aligned}
\text { percent of control } & =[\text { (treatment value } \\
& - \text { control value }) / \text { control value }] \times 100
\end{aligned}
$$

All statistical analyses were conducted with SAS (version 8e; SAS Institute Inc. 2000). For the simple bioassays, treatment effects on chlorophyll $a$ and $\mathrm{N}_{2}$ fixation were analyzed statistically using one-way analysis of variance (ANOVA, PROC GLM, factor = nutrient). Results were analyzed for the final day of the experiment, with the exception of experiment 2, where very different responses were observed on day 3 and so both days 3 and 6 were analyzed. Significance was determined using Bonferroni-adjusted $p$ values, where $\alpha$ (set at 0.05 ) was divided by the number of tests ( $n=6$ for simple bioassays; Zar 1999). Biovolume was not analyzed statistically because only one replicate was counted per treatment. Post-hoc Tukey's Studentized range tests were used to compare treatments. Factorial bioassays were analyzed using three-way, repeated-measures ANOVA (PROC MIXED, factors $=$ treatment, salinity, repeated $=$ date) for chlorophyll $a$ and $\mathrm{N}_{2}$ fixation. Five repeated-measures models with different covariance structures were fit to the data sets before selecting the model with the lowest Akaike's information criterion (AIC) value and least parameters. Degrees of freedom (df) were calculated in PROC MIXED using the KenwardRoger method, which permits decimal df values. When necessary, transformations were applied to the data to meet the ANOVA assumptions that the residuals had a mean and standard deviation of zero and were normally distributed. A range of transformations was applied and the most appropriate for meeting the assumptions was selected, usually log or cube root. Significance was again determined using Bonferroniadjusted $p$ values ( $n=4$ for factorial bioassays; Zar 1999).

\section{Results}

\section{Simple bioassays}

Similar responses to nutrient additions were obtained in all four simple nutrient addition experiments. For simplicity, the results of experiment 2, where nutrient limitation was measured in both Farmington and Gilbert bays, will first be discussed and then related to results observed in all of the simple bioassays.

In experiment 2, initial chlorophyll $a$ concentrations in Farmington Bay water were extremely high $\left(>350 \mu \mathrm{g} \cdot \mathrm{L}^{-1}\right.$; 
Fig. 2. Chlorophyll $a$ concentrations in simple bioassay experiment 2 conducted with water from $(a)$ Farmington Bay and (b) Gilbert Bay. Note different scales on $y$ axes of $(a)$ and $(b)$. Error bars are \pm 1 standard error. One-way analysis of variance (see Table 2) indicated significant nutrient effects in Farmington Bay on day 3. In Gilbert Bay, a nutrient effect was significant by day 6. Asterisks (*) indicate treatments that were significantly different than controls as determined by a post-hoc Tukey's Studentized range test. Control, diamonds; nitrogen, squares; phosphorus, triangles; nitrogen + phosphorus, circles.

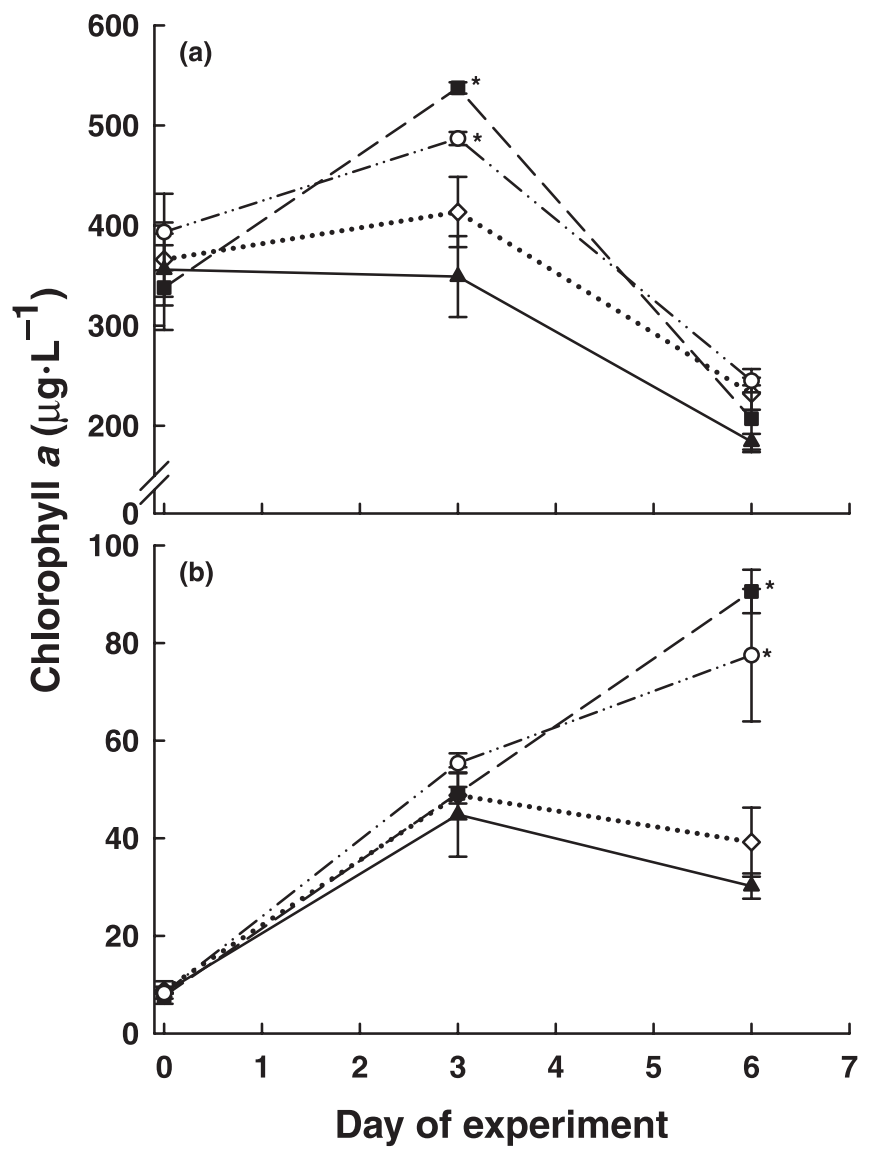

Fig. 2a). Nevertheless, chlorophyll $a$ increased significantly within 3 days when N or NP was added to the cultures, indicating strong $\mathrm{N}$ limitation of the phytoplankton community (Fig. 2a; Table 2). However, by day 6 of the experiment, the response had subsided, which was unusual among all of the short-term bioassays (Table 2). In Gilbert Bay, initial chlorophyll $a$ levels were much lower than in Farmington Bay, but a significant response to $\mathrm{N}$ and NP was also evident after 6 days (Fig. 2b; Table 2).

Responses of phytoplankton biovolume to nutrients were not as striking as the responses of chlorophyll $a$ during experiment 2. In treatments utilizing Farmington Bay water, the greatest biovolume was observed in the NP treatments and was dominated by the chlorophyte Carteria sp., with additional biovolume contributed by Dunaliella salina, D. viridis, and Oocystis sp. (Fig. 3). The $\mathrm{N}$ treatment stimulated the cyanobacterium Microcoleus sp. In contrast, little difference in biovolume was observed between the treat-
Table 2. One-way analysis of variance values ( $F$ ratios with degrees of freedom (df) and $p$ values) testing the effects of nutrient additions (factor) in the simple bioassay experiments on chlorophyll $a$ $\left(\mu \mathrm{g} \cdot \mathrm{L}^{-1}\right)$ and nitrogen fixation $\left(\mu \mathrm{g} \cdot \mathrm{L}^{-1} \cdot \mathrm{h}^{-1}\right)$.

\begin{tabular}{|c|c|c|c|c|c|}
\hline \multirow[b]{2}{*}{ Experiment } & \multirow[b]{2}{*}{ Day } & \multicolumn{2}{|c|}{ Chlorophyll $a$} & \multicolumn{2}{|c|}{ Nitrogen fixation } \\
\hline & & $F_{[\mathrm{df}]}$ & $p$ & $F_{[\mathrm{df}]}$ & $p$ \\
\hline 1 & 6 & $175 \cdot 0_{[3,8]}$ & $<0.01$ & $7.3_{[3,8]}$ & $<0.01 *$ \\
\hline \multirow[t]{2}{*}{2 Farmington } & 3 & $9.3_{[3,8]}$ & $<0.01$ & $2.0_{[3,8]}$ & 0.19 \\
\hline & 6 & $1.9_{[3,8]}$ & 0.21 & $0.8_{[3,6]}$ & 0.56 \\
\hline \multirow[t]{2}{*}{2 Gilbert } & 3 & $0.7_{[3,8]}$ & 0.6 & $2.3_{[3,8]}$ & 0.16 \\
\hline & 6 & $14.4_{[3,8]}$ & $<0.01$ & $1.2_{[3,8]}$ & 0.38 \\
\hline 3 & 6 & $119 \cdot 1_{[3,8]}$ & $<0.01$ & ND & ND \\
\hline 4 & 6 & $67 \cdot 1_{[3,8]}$ & $<0.01$ & $1.0_{[3,8]}$ & 0.44 \\
\hline
\end{tabular}

Note: Bold type indicates Bonferroni-adjusted significance, $p<0.008$. ND indicates that $F$ ratio and $p$ value could not be determined because every value was zero for all treatments and replicates.

*Although this was significant, the nitrogen-fixation rates here were actually very low and near the detection limit of the measurement technique.

Fig. 3. Phytoplankton biovolume on day 6 in simple bioassay experiment 2 conducted with water from both Farmington Bay and Gilbert Bay. C, control; N, + nitrogen; P, + phosphorus; NP, + nitrogen + phosphorus. Diatoms, open bars; green algae, hatched bars; cyanobacteria, solid bars; chrysophytes, shaded bars.

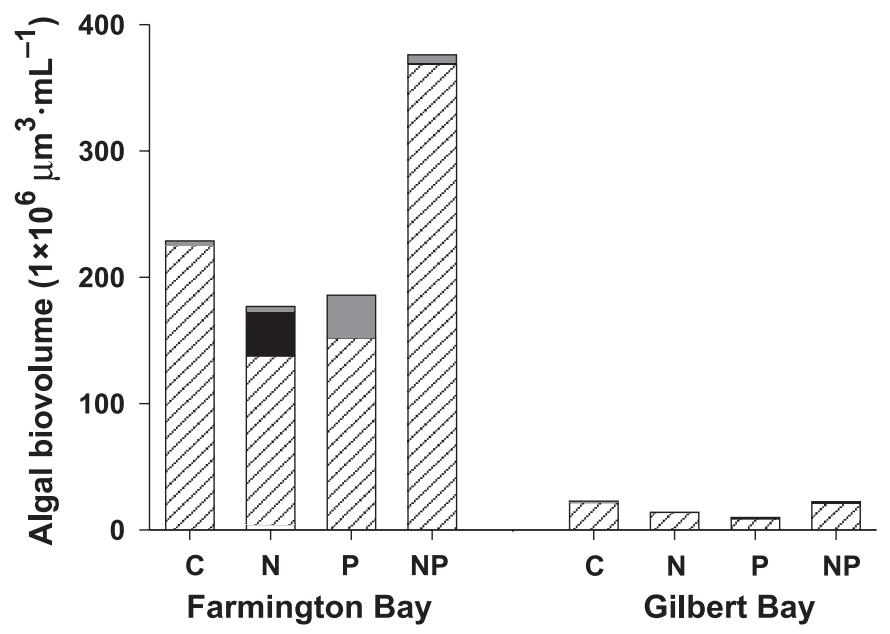

ments in Gilbert Bay, all of which were dominated by the small D. viridis (Fig. 3).

When the results from all of the simple bioassays are compared, it is clear that N and NP treatments routinely stimulated chlorophyll $a$ (Fig. 4a). In every experiment except experiment 2, N limitation was strongly indicated by chlorophyll $a$ responses on day 6 (Fig. 4a). Low, negative responses in chlorophyll $a$ were usually observed in P treatments, although these differences were never significant. Generally, phytoplankton biovolume decreased relative to controls, except for small positive or negative responses in the NP treatments (Fig. 4b). $\mathrm{N}_{2}$ fixation showed very small and usually insignificant responses (Table 2) to nutrient additions in the simple bioassay experiments, and rates were routinely near or below the level of detection of the acetylene reduction assay used (Fig. $4 c$ ). The lack of $\mathrm{N}_{2}$-fixation 
Fig. 4. Summary of responses of phytoplankton to nutrient additions in all experiments on day 6 in the simple bioassays. Responses are reported as percent responses above mean control levels for $(a)$ chlorophyll $a,(b)$ total phytoplankton biovolume, and $(c)$ nitrogen fixation. Zero (0) indicates no difference from the response of control treatments. Missing bars indicate that no comparison was possible because of lack of either control or nutrient treatment. Treatments were + nitrogen $(\mathrm{N}$, solid bars $),+$ phosphorus $(\mathrm{P}$, open bars), + nitrogen + phosphorus (NP, hatched bars). Experiment numbers (Table 1) shown are, from left to right, 1, 2 Farmington Bay, 2 Gilbert Bay, 3, and 4. An asterisk (*) indicates the treatment response was significantly different from the control value in $(a)$ and $(c)$. Significance was assessed using a one-way analysis of variance for nutrient treatment followed by a post-hoc Tukey's Studentized range test; test statistics are shown in Table 2. No replicates were analyzed for biovolume measurements shown in $(b)$, so treatments could not be compared statistically.

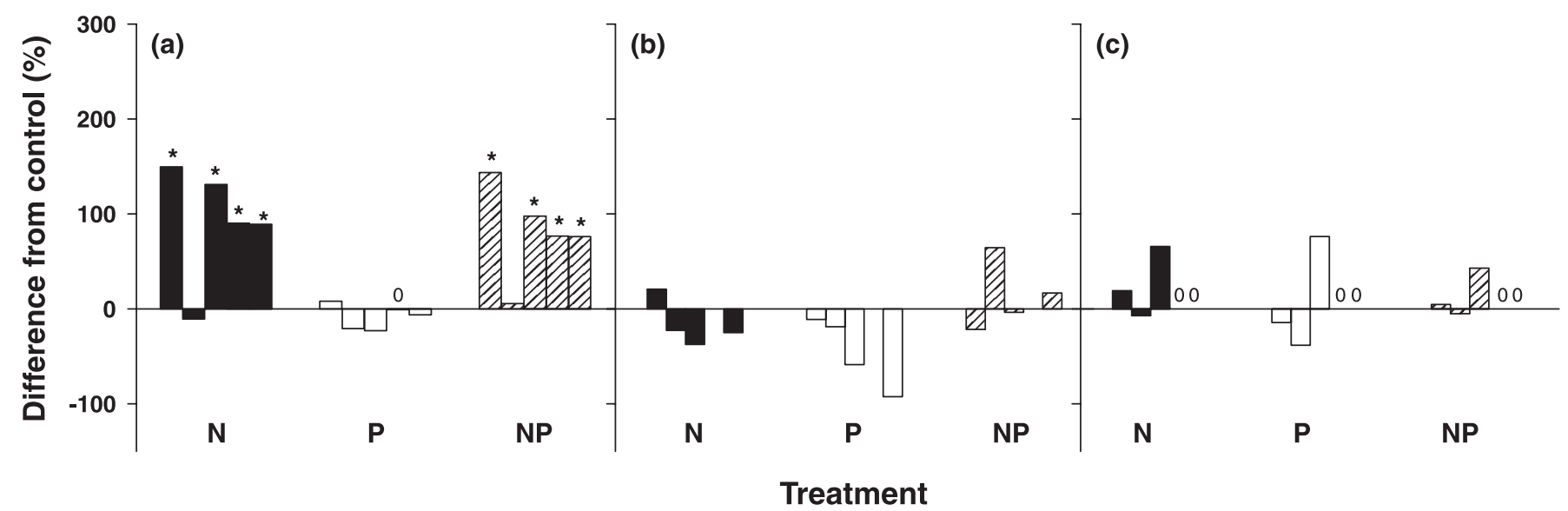

responses in these short-term assays was expected, given that few, if any, $\mathrm{N}_{2}$-fixing taxa were present (e.g., Fig. 3).

\section{Factorial bioassays}

Very different results were obtained between the four longterm factorial bioassay experiments. Again for simplicity we will first discuss the results of a single experiment (experiment B), where we observed interesting responses to nutrient and salinity treatments, and then relate these to results from all the factorial bioassays.

In experiment $\mathrm{B}$, there were short-term responses to $\mathrm{N}$ additions, but in the long-term, the plankton responded primarily to $\mathrm{P}$ additions (Fig. 5a; Appendix A). In the lowest salinity $\left(10 \mathrm{~g} \cdot \mathrm{L}^{-1}\right)$ treatments, there were only small responses of chlorophyll $a$ to the nutrient treatments (Fig. 5a). N stimulated chlorophyll $a$ production after 9 days only in the $70 \mathrm{~g} \cdot \mathrm{L}^{-1}$ salinity treatment (Fig. $5 d$ ). However, after 30 days, $\mathrm{P}$ stimulated chlorophyll $a$ above control treatments in the 30, 50, and $70 \mathrm{~g} \cdot \mathrm{L}^{-1}$ salinity treatments (Figs. 5b-5d). A three-way repeated-measures ANOVA indicated a significant three-way interaction between salinity, nutrient, and day of experiment for chlorophyll $a$ (Table 3).

$\mathrm{N}_{2}$-fixation rates in this experiment were initially near zero, but rates increased both in the controls and particularly in $\mathrm{P}$ treatments during the long incubation (Figs. 5e-5h). In the controls, $\mathrm{N}_{2}$-fixation rates increased most in the 10 and $30 \mathrm{~g} \cdot \mathrm{L}^{-1}$ treatments (Figs. 5e, 5f), with limited increases at 50 and $70 \mathrm{~g} \cdot \mathrm{L}^{-1}$. At $10 \mathrm{~g} \cdot \mathrm{L}^{-1}$ salinity, peak $\mathrm{N}_{2}$-fixation rates in the $\mathrm{P}$ treatment were observed by day 15 (Fig. $5 e$ ), but at higher salinities, the peak was delayed to day 23 (30 and $50 \mathrm{~g} \cdot \mathrm{L}^{-1}$; Figs. $5 e$ and $5 \mathrm{~g}$ ) or day $30\left(70 \mathrm{~g} \cdot \mathrm{L}^{-1}\right.$; Fig. $\left.5 h\right)$. The relatively high $\mathrm{N}_{2}$-fixation rate on day 30 in the $+\mathrm{P}, 70 \mathrm{~g} \cdot \mathrm{L}^{-1}$ salinity treatment was due to a high rate in only one of the three replicates. A three-way repeated-measures ANOVA indicated a significant three-way interaction between salinity, nutrient, and day of experiment for $\mathrm{N}_{2}$ fixation (Table 3). Cyanobacteria comprised $60 \%-80 \%$ of the phytoplankton biovolume in $\mathrm{P}$ treatments at all salinities on day 30 of the experiment (Fig. 6). Nodularia spumigena, a $\mathrm{N}_{2}$-fixing taxon with heterocytes, was the dominant cyanobacteria. $\mathrm{N}$ additions suppressed $\mathrm{N}_{2}$ fixation (Figs. 5e-5h) and cyanobacterial abundances (Fig. 6). When $\mathrm{N}_{2}$-fixation rates are normalized to the biomass of cyanobacteria on day 30 of the experiment, $\mathrm{P}$ stimulated $\mathrm{N}_{2}$ fixation of cyanobacteria $98 \%$ above control levels, whereas $\mathrm{N}$ suppressed $\mathrm{N}_{2}$ fixation $100 \%$ below control levels.

Salinity exerted an important control on $\mathrm{N}_{2}$ fixation in all of the factorial experiments. When maximum $\mathrm{N}_{2}$-fixation rate measurements from the control and $\mathrm{P}$ treatments from all factorial experiments are combined, the results, although variable, indicate that maximum $\mathrm{N}_{2}$-fixation rates were relatively independent of salinity between 10 and $70 \mathrm{~g} \cdot \mathrm{L}^{-1}$. However, little or no $\mathrm{N}_{2}$ fixation was observed at salinities greater than $70 \mathrm{~g} \cdot \mathrm{L}^{-1}$ (Fig. 7). In all four experiments, repeated-measures ANOVA indicated a significant three-way interaction between salinity, nutrient supply, and day that controlled both $\mathrm{N}_{2}$ fixation and chlorophyll $a$ (Table 3 ). However, examining the mean $\mathrm{N}_{2}$-fixation rates from the experiments showed that the stimulatory response to $\mathrm{P}$ additions at low salinities observed in factorial experiment B was rare. Very small increases in $\mathrm{N}_{2}$ fixation due to $\mathrm{P}$ addition were observed on day 28 in experiment $A$, days 14 and 21 in experiment $C$, and day 28 in experiment D (Appendix A). However, these increases only translated into a stimulation of chlorophyll $a$ production by $\mathrm{P}$ in three salinity treatments in the first two experiments (experiment A, day 28, $30 \mathrm{~g} \cdot \mathrm{L}^{-1}$; experiment $\mathrm{B}$, days 23 and 30,30 and $50 \mathrm{~g} \cdot \mathrm{L}^{-1}$; Appendix A). These increases were all concurrent with a response of $\mathrm{N}_{2}$ fixation to $\mathrm{P}$. However, in a majority of the salinity treatments less than $70 \mathrm{~g} \cdot \mathrm{L}^{-1}$, there was no stimulation of $\mathrm{N}_{2}$ fixation by $\mathrm{P}$, and $\mathrm{N}$ limitation of chlorophyll $a$ was routinely observed. In 
Fig. 5. $(a-d)$ Chlorophyll $a$ and $(e-h)$ nitrogen-fixation responses of plankton from Farmington Bay grown in four salinities $(a$ and $e$, $10 \mathrm{~g} \cdot \mathrm{L}^{-1} ; b$ and $f, 30 \mathrm{~g} \cdot \mathrm{L}^{-1} ; c$ and $g, 50 \mathrm{~g} \cdot \mathrm{L}^{-1} ; d$ and $\left.h, 70 \mathrm{~g} \cdot \mathrm{L}^{-1}\right)$ to $\mathrm{N}$ or P additions during factorial experiment B. Note the delays in peak nitrogen-fixation rates with increasing salinities. Error bars are \pm 1 standard error. Control, diamonds; nitrogen, squares; phosphorus, triangles. A three-way repeated-measures analysis of variance indicated a significant three-way interaction between nutrient, salinity, and date; test statistics are shown in Table 3.

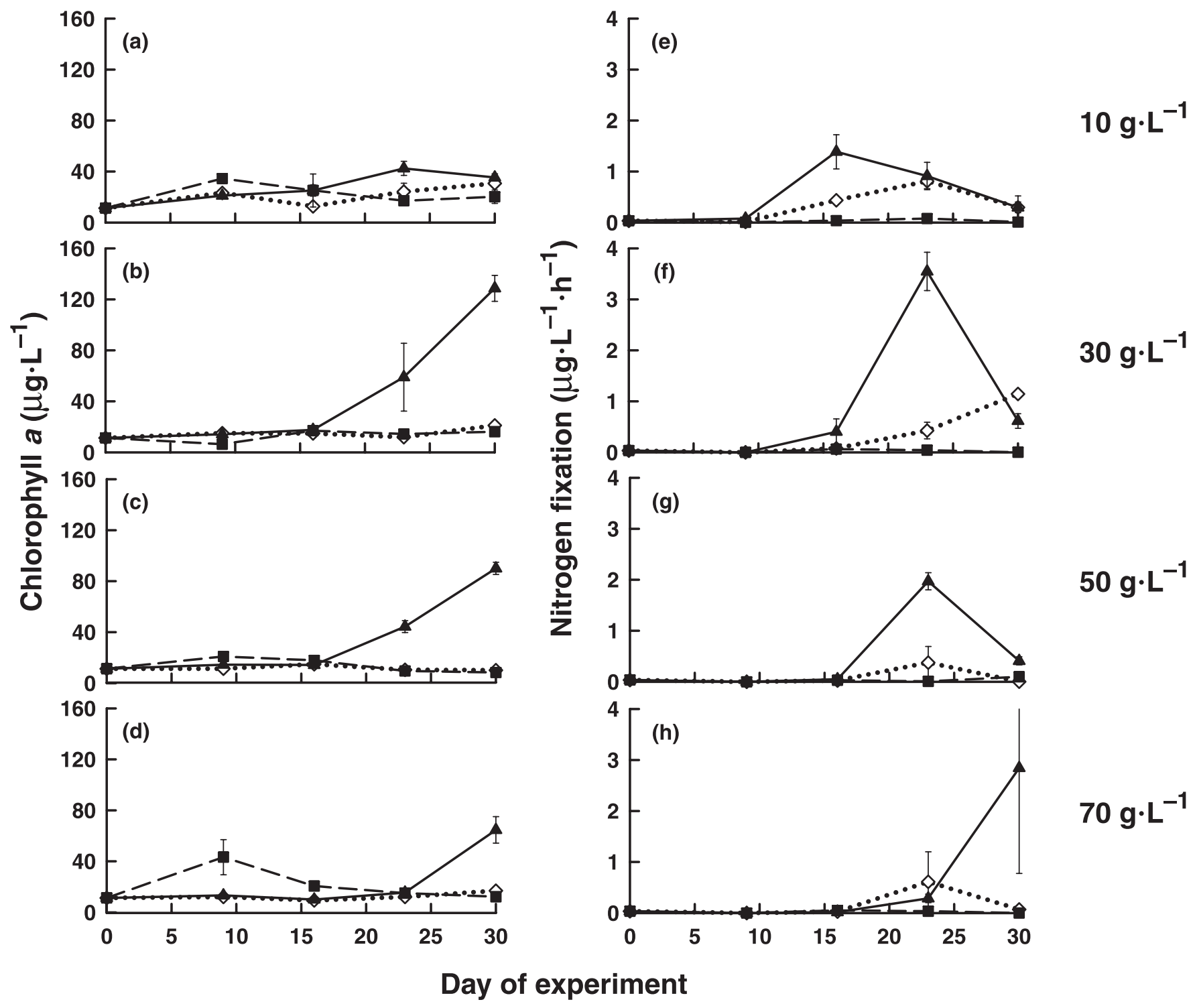

each of these instances, there were no cyanobacteria with heterocytes observed at the end of the experiment, indicating that $\mathrm{N}_{2}$ fixation could not occur to facilitate the switch from $\mathrm{N}$ to $\mathrm{P}$ limitation because of the lack of $\mathrm{N}_{2}$-fixing taxa. At salinities greater than $70 \mathrm{~g} \cdot \mathrm{L}^{-1}$, strong limitation of chlorophyll $a$ by $\mathrm{N}$ was uniformly noted, with no stimulation of chlorophyll $a$ by $\mathrm{P}$ in any instance (Appendix A).

In the short-term factorial experiment I, salinity exerted a very clear effect on both chlorophyll $a$ and $\mathrm{N}_{2}$ fixation (Fig. 8). In this experiment, there was no significant difference in chlorophyll $a$ and $\mathrm{N}_{2}$-fixation rates between the control and $\mathrm{P}$ treatments, indicated by repeated-measures three-way ANOVA (Fig. 8). Chlorophyll $a$ concentrations decreased in the salinity treatments greater than $50 \mathrm{~g} \cdot \mathrm{L}^{-1}$ through the duration of the experiment, while increasing in salinity treatments less than $50 \mathrm{~g} \cdot \mathrm{L}^{-1}$ (Fig. 8a). $\mathrm{N}_{2}$ fixation ceased at salinities greater than $60 \mathrm{~g} \cdot \mathrm{L}^{-1}$ on all days of the study, but continued at high rates at 20 and $40 \mathrm{~g} \cdot \mathrm{L}^{-1}$ salinities (Fig. $8 b$ ).

\section{Discussion}

Nutrient effects on phytoplankton growth

Both the short-term bioassays and high salinity treatments in the factorial bioassays demonstrated that the extant phytoplankton populations in Farmington Bay and Gilbert Bay were typically N-limited. $\mathrm{N}$ limitation has been found in previous studies of Great Salt Lake phytoplankton. Stephens and Gillespie (1976) found that densities of $D$. viridis increased in response to $\mathrm{N}$ additions but not to $\mathrm{P}$ additions in laboratory cultures of Gilbert Bay water (salinity $135 \mathrm{~g} \cdot \mathrm{L}^{-1}$ ). Porcella and Holman (1972) also found a positive response of Dunaliella sp. to $\mathrm{N}$ and not to $\mathrm{P}$ when salinity in Gilbert 
Table 3. Statistics ( $F$ ratios with degrees of freedom $(\mathrm{df})$ and $p$ values) for the factorial experiments.

\begin{tabular}{|c|c|c|c|c|}
\hline \multirow[b]{2}{*}{ Factor } & \multicolumn{2}{|l|}{ Chlorophyll $a$} & \multicolumn{2}{|c|}{ Nitrogen fixation } \\
\hline & $F_{[\mathrm{df}]}$ & $p$ & $F_{[\mathrm{df}]}$ & $p$ \\
\hline \multicolumn{5}{|l|}{ Experiment A } \\
\hline Nut & $49.0_{[2,19.6]}$ & $<0.01$ & $7.3_{[2,18]}$ & $<0.01$ \\
\hline S & $2.4_{[2,19.6]}$ & 0.12 & $33 \cdot 6_{[2,18]}$ & $<0.01$ \\
\hline $\mathrm{D}$ & $22.2_{[3,22]}$ & $<0.01$ & $10.0_{[1,18]}$ & $<0.01$ \\
\hline Nut $\times S$ & $8.8_{[4,19.6]}$ & $<0.01$ & $8 \cdot 6_{[4,18]}$ & $<0.01$ \\
\hline $\mathrm{D} \times \mathrm{Nut}$ & $17.9_{[6,27.2]}$ & $<0.01$ & $15.5_{[2,18]}$ & $<0.01$ \\
\hline $\mathrm{D} \times \mathrm{S}$ & $13 \cdot 3_{[6,27.2]}$ & $<0.01$ & $5 \cdot 0_{[2,18]}$ & 0.02 \\
\hline $\mathrm{D} \times$ Nut $\times \mathrm{S}$ & $3.2_{[12,31.5]}$ & $<0.01$ & $19.9_{[4,18]}$ & $<0.01$ \\
\hline \multicolumn{5}{|l|}{ Experiment B } \\
\hline Nut & $69 \cdot 2_{[2,25.3]}$ & $<0.01$ & $118.8_{[2,31]}$ & $<0.01$ \\
\hline$S$ & $4 \cdot 2_{[2,25.3]}$ & 0.02 & $19.7_{[4,37]}$ & $<0.01$ \\
\hline $\mathrm{D}$ & $50.1_{[3,44]}$ & $<0.01$ & $120.8_{[4,14.6]}$ & $<0.01$ \\
\hline Nut $\times S$ & $10.6_{[6,25.3]}$ & $<0.01$ & $5.3_{[6,31.2]}$ & $<0.01$ \\
\hline $\mathrm{D} \times \mathrm{Nut}$ & $61.0_{[6,50.1]}$ & $<0.01$ & $13.5_{[6,49.7]}$ & $<0.01$ \\
\hline $\mathrm{D} \times \mathrm{S}$ & $8.6_{[9,52.8]}$ & $<0.01$ & $7.0_{[9,52.2]}$ & $<0.01$ \\
\hline $\mathrm{D} \times$ Nut $\times \mathrm{S}$ & $6.9_{[18,54.1]}$ & $<0.01$ & $6.6_{[17,52.2]}$ & $<0.01$ \\
\hline \multicolumn{5}{|l|}{ Experiment C } \\
\hline Nut & $119.8_{[2,24.7]}$ & $<0.01$ & $37.4_{[2,18.4]}$ & $<0.01$ \\
\hline $\mathrm{S}$ & $10.0_{[3,24.7]}$ & $<0.01$ & $88.7_{[3,18.4]}$ & $<0.01$ \\
\hline $\mathrm{D}$ & $138.1_{[4,51.9]}$ & $<0.01$ & $6.6_{[3,19.3]}$ & $<0.01$ \\
\hline Nut $\times S$ & $4.8_{[6,24.6]}$ & $<0.01$ & $25.4_{[6,18.2]}$ & $<0.01$ \\
\hline $\mathrm{D} \times$ Nut & $33.0_{[8,61.7]}$ & $<0.01$ & $10.1_{[6,24.8]}$ & $<0.01$ \\
\hline $\mathrm{D} \times \mathrm{S}$ & $5.9_{[12,66.2]}$ & $<0.01$ & $5.0_{[9,28.2]}$ & $<0.01$ \\
\hline $\mathrm{D} \times$ Nut $\times \mathrm{S}$ & $4.3_{[24,69.2]}$ & $<0.01$ & $7.0_{[18,32.1]}$ & $<0.01$ \\
\hline \multicolumn{5}{|l|}{ Experiment D } \\
\hline Nut & $449.2_{[2,31.8]}$ & $<0.01$ & $1.5_{[2,32.2]}$ & 0.24 \\
\hline S & $38.6_{[4,31.8]}$ & $<0.01$ & $8.8_{[4,32]}$ & $<0.01$ \\
\hline $\mathrm{D}$ & $107.4_{[3,35.6]}$ & $<0.01$ & $23.3_{[3,45.8]}$ & $<0.01$ \\
\hline Nut $\times S$ & $30.2_{[8,31.8]}$ & $<0.01$ & $1.1_{[8,31.9]}$ & 0.36 \\
\hline $\mathrm{D} \times \mathrm{Nut}$ & $131.0_{[6,44.4]}$ & $<0.01$ & $2.8_{[6,52.1]}$ & 0.02 \\
\hline $\mathrm{D} \times \mathrm{S}$ & $105.6_{[12,52.6]}$ & $<0.01$ & $13 \cdot 1_{[12,56]}$ & $<0.01$ \\
\hline $\mathrm{D} \times$ Nut $\times \mathrm{S}$ & $27.5_{[24,56.5]}$ & $<0.01$ & $2.4_{[23,56.8]}$ & $<0.01$ \\
\hline
\end{tabular}

Note: Analyses were three-way repeated-measures analysis of variance (factors = nutrient $($ Nut), salinity $(\mathrm{S})$, and date (D)). Bold type indicates Bonferroni-adjusted significance, $p<0.0125$. The two response variables measured were chlorophyll $a\left(\mu \mathrm{g} \cdot \mathrm{L}^{-1}\right)$ and nitrogen fixation $\left(\mu \mathrm{g} \cdot \mathrm{L}^{-1} \cdot \mathrm{h}^{-1}\right)$.

Bay was near $160 \mathrm{~g} \cdot \mathrm{L}^{-1}$. Wurtsbaugh (1988) tested Gilbert Bay water during high water years (1985-1986) when salinities were $50 \mathrm{~g} \cdot \mathrm{L}^{-1}$ and found that chlorophyll $a$ concentrations responded significantly to $\mathrm{N}$ additions, but only marginally to $\mathrm{P}$ additions in 8-day bioassays. Moreover, Javor's review (1989) of the literature on saline lakes indicates that phytoplankton production in most saline lakes is N-limited.

The phytoplankton in our experiments always responded to $\mathrm{N}$ additions within 3-8 days by incrementing chlorophyll $a$ levels, often as much as $150 \%-250 \%$ above controls. Phytoplankton biovolume did not, however, respond consistently to the nutrient additions in the simple or factorial bioassays. A linear regression between biovolume and chlorophyll $a$ from factorial bioassay treatments where both were
Fig. 6. Phytoplankton biovolume on day 30 of factorial experiment $\mathrm{B}$ at salinities of $10,30,50$, and $70 \mathrm{~g} \cdot \mathrm{L}^{-1}$. Note higher biovolume of cyanobacteria in the control and $\mathrm{P}$ treatments, particularly at low salinities. C, control; N, + nitrogen; $\mathrm{P},+$ phosphorus. Diatoms, open bars; green algae, hatched bars; cyanobacteria, solid bars; chrysophytes, shaded bars.

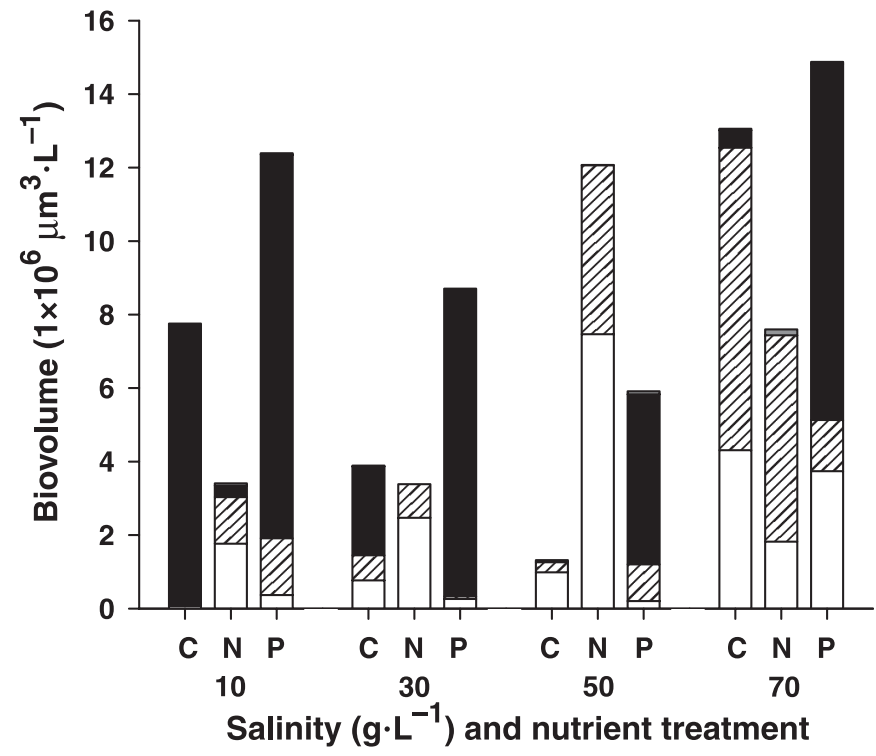

Fig. 7. Maximum nitrogen-fixation rates observed in relation to treatment salinities for all factorial experiments in the control (solid circles) and phosphorus (open circles) treatments. Maximum nitrogen-fixation rates showed no clear relationship with salinity from 10 to $70 \mathrm{~g} \cdot \mathrm{L}^{-1}$, but declined to near zero at salinities greater than $70 \mathrm{~g} \cdot \mathrm{L}^{-1}$. Maximum nitrogen-fixation rates occurred on different days in the different experiments. Note log scale on the $y$ axis.

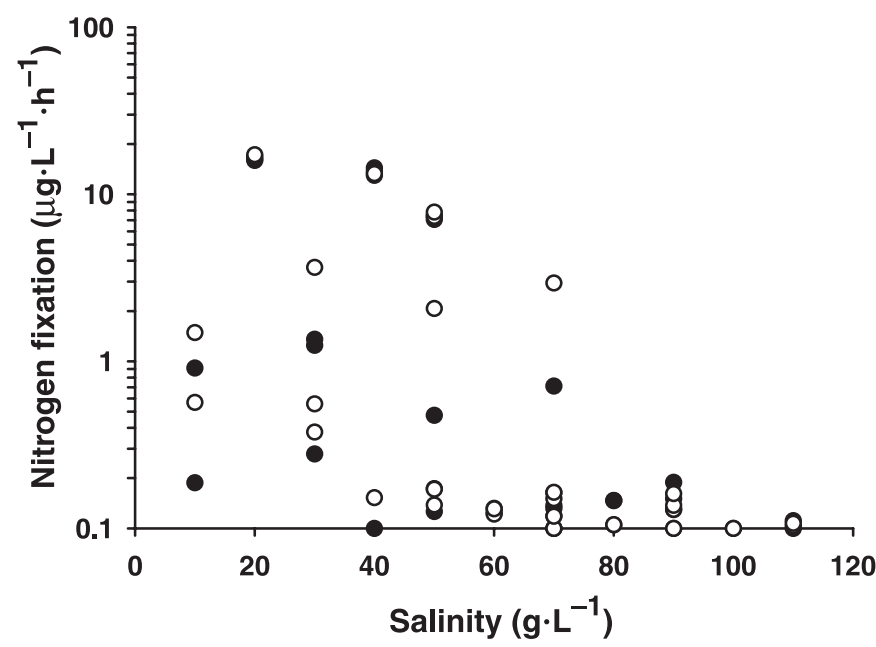

collected revealed a significant but weak relationship $\left(r^{2}=\right.$ $0.16, F_{[1,37]}=6.5, p=0.02$, chlorophyll $a \mu \mathrm{g} \cdot \mathrm{L}^{-1}=3.1 \times 10^{-6}$ $\times$ (biovolume $\mu \mathrm{m}^{3} \cdot \mathrm{mL}^{-1}$ ) +9.2 ). This response has been described in other similar experiments in lake and stream ecosystems (e.g., Greenwood and Rosemond 2005). This response could result in an increased capacity to capture sunlight and, in turn, increase photosynthesis in light-limited 
Fig. 8. (a) Chlorophyll $a$ and (b) nitrogen-fixation results from short-term factorial experiment I on the three sampling dates of the experiment. Note $(i)$ how nitrogen fixation peaks later at higher salinities and (ii) how nitrogen fixation ceases on all days at greater than $60 \mathrm{~g} \cdot \mathrm{L}^{-1}$ salinity. Error bars are \pm 1 standard error. A three-way repeated-measures analysis of variance showed significant interactions between date and salinity on chlorophyll $a$ $\left(F_{[12,27.6]}=92.8, p<0.01\right)$ and on nitrogen fixation $\left(F_{[12,18.4]}=\right.$ $18.4, p<0.01)$. There was no significant individual or interaction effect of nutrient treatment for either response, so results from the control and phosphorus treatments were combined for this figure. Day 1, diamonds; day 3, squares; day 6, triangles.

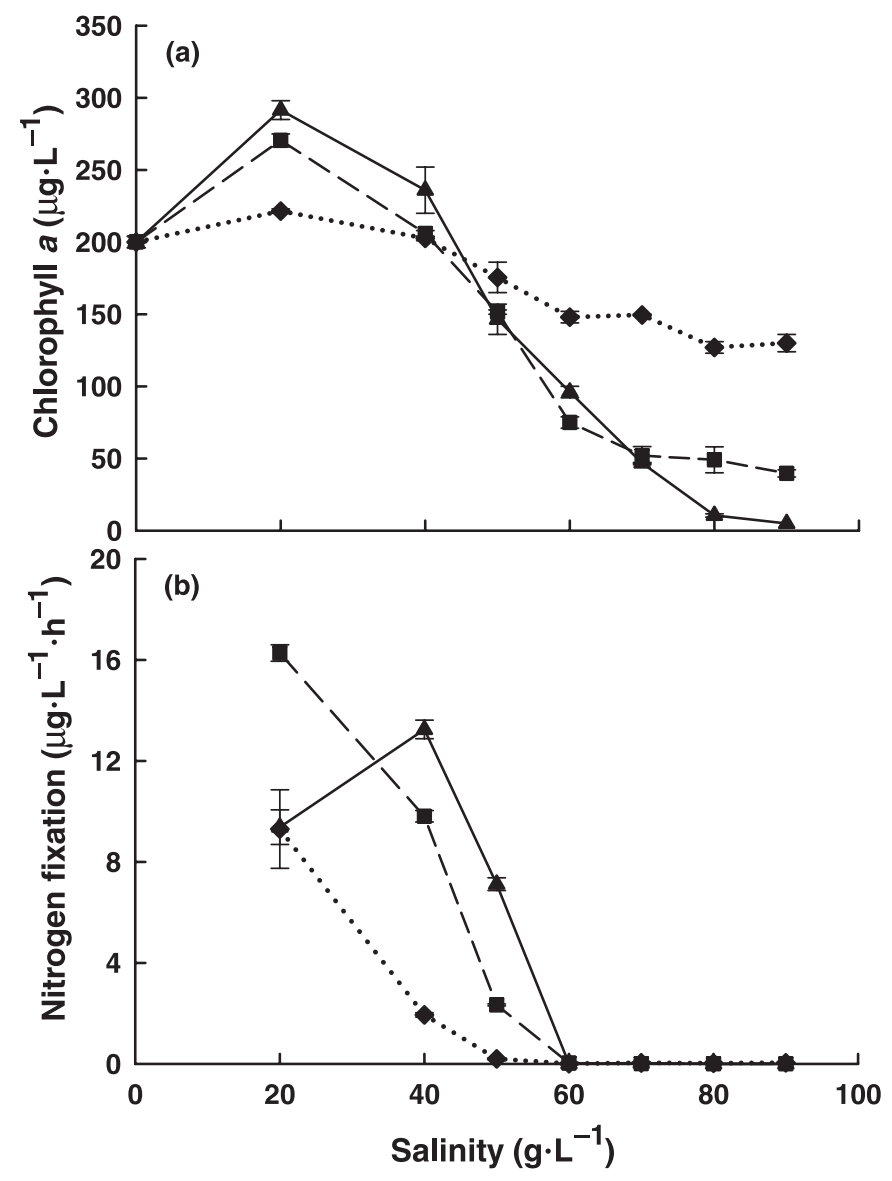

situations. However, increasing chlorophyll $a$ per cell could also be a response to shading, either because our experimental light intensities were moderate or because of shading differences within each treatment. Chlorophyll $a$ - biovolume ratios did not show a clear pattern related to treatment. However, without biovolume estimates from all sampling dates, it was difficult to uncover relationships using this ratio.

In most of the short-term bioassay experiments that have been conducted with Great Salt Lake water, P additions actually decrease phytoplankton abundances. A decrease in chlorophyll $a$ and biovolume occurred as a result of $\mathrm{P}$ addition in our short-term bioassays, and it was also reported in those of Stephens and Gillespie (1976) and Porcella and Holman (1972), but not in the assays of Wurtsbaugh (1988). This decrease could be due to competition between phytoplankton and heterotrophic bacteria for $\mathrm{P}$, as the latter are superior competitors for this nutrient (Brussaard and Riegman
Fig. 9. Generalized relationship between phosphorus and salinity identifying domains where nitrogen fixation can or cannot occur in the Great Salt Lake, causing nutrient limitation of the phytoplankton community to vary between nitrogen and phosphorus limitation.

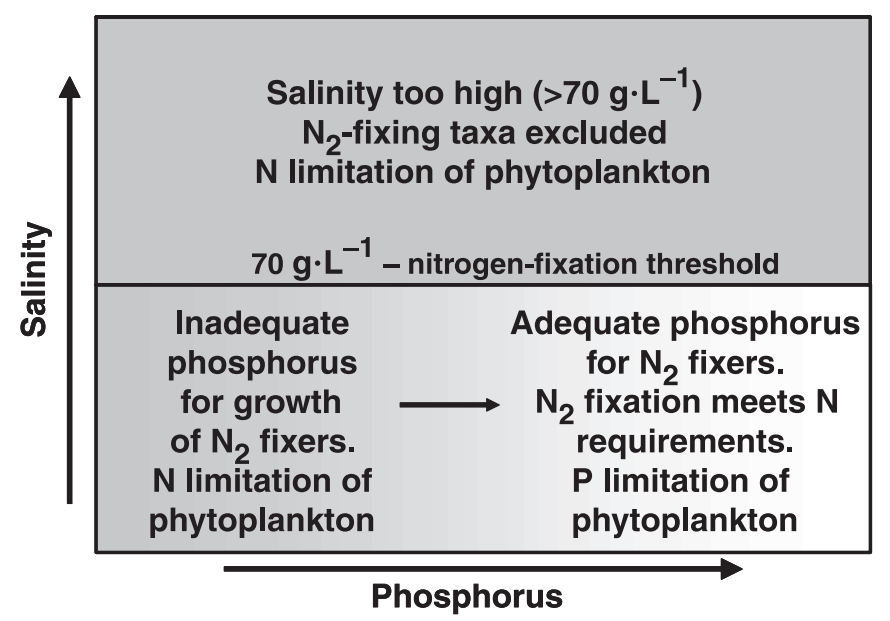

1998). The increased bacterial populations might then compete with phytoplankton populations for some other limiting nutrient, such as N. Although this mechanism has not been demonstrated in the Great Salt Lake, the potential that it may occur reminds us that the phytoplankton open-water community is a diverse, interacting assemblage of microbes and metazoans, and complex responses to experiments may be driven by these often ignored interactions.

\section{Effects of salinity on $\mathrm{N}_{2}$ fixation and $\mathrm{N}_{2}$-fixing cyanobacteria}

Salinity exerted an important control on $\mathrm{N}_{2}$ fixation in the long-term experiments and sometimes interacted with $\mathrm{P}$ to control $\mathrm{N}_{2}$ fixation. Our results generally showed that $\mathrm{N}_{2}$ fixation could occur up to salinities of $50-70 \mathrm{~g} \cdot \mathrm{L}^{-1}$. These salinities were higher than levels found by Lehtimäki et al. (1997) and Mazur-Marzec et al. (2005) that restricted growth, $\mathrm{N}_{2}$ fixation, and hepatotoxin production of Baltic Sea N. spumigena $\left(<30 \mathrm{~g} \cdot \mathrm{L}^{-1}\right)$. Pinckney et al. (1995) found that decreasing salinity from 90 to $45 \mathrm{~g} \cdot \mathrm{L}^{-1}$ significantly increased $\mathrm{N}_{2}$-fixation rates in a microbial mat dominated by Microcoleus chthonoplastes, which lacked heterocytes, and rates were increased approximately $75 \%$ by $\mathrm{P}$ addition to cultures held in the dark. Herbst (1998) found that the $\mathrm{N}_{2}$ fixation by a benthic periphyton community from Mono Lake was decreased by nearly $50 \%$ when salinities increased from 50 to $100 \mathrm{~g} \cdot \mathrm{L}^{-1}$, and rates were reduced by $90 \%$ at $150 \mathrm{~g} \cdot \mathrm{L}^{-1}$ salinity. Dubinin et al. (1992) reported $\mathrm{N}_{2}$ fixation by $M$. chthonoplastes in salinities up to $150 \mathrm{~g} \cdot \mathrm{L}^{-1}$, but in those experiments, the organism was grown at $60 \mathrm{~g} \cdot \mathrm{L}^{-1}$ salinity and only exposed to the higher test salinities for $6 \mathrm{~h}$. Camacho and de Wit (2003) also noted P stimulation of $\mathrm{N}_{2}$ fixation in $M$. chthonoplastes communities at $80 \mathrm{~g} \cdot \mathrm{L}^{-1}$ salinity. However, they indicate that $\mathrm{N}_{2}$ fixation was more likely carried out by heterotrophic bacteria in the biofilm because M. chthonoplastes does not contain nitrogenase. It is also possible that low-salinity and anoxic microzones in biofilms allow $\mathrm{N}_{2}$ fixation at salinities higher than those possible in 
the homogenous water column. In our experiments, biofilms sometimes developed in the bottom of the incubation jars towards the end of the long-term experiments, but because we did not assay these communities, it is impossible to determine whether $\mathrm{N}_{2}$ fixation was occurring in these mats. All of these results indicate that increasing salinity dramatically depresses $\mathrm{N}_{2}$-fixation rates in a variety of environments and are consistent with the responses to salinity observed in our experiment.

Salinity likely limits the survival and distribution of cyanobacteria in hypersaline lakes. A monitoring study of a salinity gradient in Farmington Bay in 1971 (Carter 1971) indicated that Nodularia sp. was usually not abundant in areas where salinities were greater than $70 \mathrm{~g} \cdot \mathrm{L}^{-1}$ but was abundant at lower salinities. Stephens (1990) noted that N. spumigena appeared in Gilbert Bay of the Great Salt Lake when salinities decreased to $60 \mathrm{~g} \cdot \mathrm{L}^{-1}$ during the mid-1980s. It is possible, however, that $N$. spumigena was primarily found in Farmington Bay and had advected into Gilbert Bay. A mesocosm study in Mono Lake examined the community composition of benthic periphyton mats at five salinity levels between 50 and $150 \mathrm{~g} \cdot \mathrm{L}^{-1}$. The filamentous cyanobacteria Oscillatoria sp. only occurred in salinity treatments between 50 and $100 \mathrm{~g} \cdot \mathrm{L}^{-1}$, and no other cyanobacteria species were present at any salinity (Herbst and Blinn 1998).

Hypersaline conditions are stressful for all organisms because of the coupled effects of osmotic stress and ionic stress resulting from high concentrations of ions. Mackay et al. (1983) demonstrated that cyanobacteria that live in saline environments (both marine and hypersaline) have the ability to synthesize osmoregulatory compounds that permit growth in saline solutions. These compounds inhibit $\mathrm{Na}^{+}$influx into cells, in turn allowing cyanobacteria to tolerate saline conditions (Apte et al. 1987). More recent work has shown that $\mathrm{N}_{2}$-fixing cyanobacteria are more susceptible to ionic stress than to osmotic stress, and Anabaena species will cease $\mathrm{N}_{2}$ fixation and decrease growth by $50 \%$ within 5 days of exposure to salinity stress (Fernandes et al. 1993). This suggests that the salinity effects we see on $\mathrm{N}_{2}$ fixation in Farmington Bay are likely a combination of salinity stress leading to (i) decreased $\mathrm{N}_{2}$-fixation rates and (ii) decreased growth and (or) death of $\mathrm{N}_{2}$-fixing cyanobacteria.

\section{Salinity and nutrient interactions in Farmington Bay}

The compiled results of all our factorial bioassay experiments suggest that given the salinities normally observed in Farmington Bay $\left(<70 \mathrm{~g} \cdot \mathrm{L}^{-1}\right)$, $\mathrm{P}$ can stimulate growth and $\mathrm{N}_{2}$-fixation rates of cyanobacteria, indicating that the phytoplankton community there is P-limited (Fig. 9). In our experiments, this stimulation by $\mathrm{P}$ was certainly due to increased growth of cyanobacteria, but not always due to increased $\mathrm{N}_{2}$-fixation rates per cyanobacterial cell. When $\mathrm{N}_{2}$-fixation rates are normalized for cell biovolume, they range from $40 \%$ lower to $100 \%$ greater in P treatments than in the controls at salinities of $<70 \mathrm{~g} \cdot \mathrm{L}^{-1}$. During droughts when lake elevations drop, salinities can rise above $70 \mathrm{~g} \cdot \mathrm{L}^{-1}$ in Farmington Bay, and in Gilbert Bay, salinities are almost always above $70 \mathrm{~g} \cdot \mathrm{L}^{-1}$. At salinities greater than $70 \mathrm{~g} \cdot \mathrm{L}^{-1}$, the phytoplankton community would remain $\mathrm{N}$-limited, regardless of the $\mathrm{P}$ concentrations, because $\mathrm{N}_{2}$-fixing taxa are excluded from the phytoplankton community (Fig. 9). This has clearly been illustrated in our experiments, where $\mathrm{N}$ limitation is always observed at salinities greater than or equal to $70 \mathrm{~g} \cdot \mathrm{L}^{-1}$, and cyanobacteria are usually absent from the phytoplankton community. If nutrients were to be controlled to reduce eutrophication in Farmington Bay, the expected salinity levels would thus need to be incorporated into the decision process. At low salinities (approximately $<70 \mathrm{~g} \cdot \mathrm{L}^{-1}$ ), $\mathrm{P}$ may need to be controlled. At higher salinities, $\mathrm{N}$ control would be appropriate (Fig. 9).

It should also be noted from our results that $\mathrm{P}$ limitation of phytoplankton communities was not always observed at low salinities, because cyanobacteria were not always present in our low-salinity treatments. It is possible that this occurred because in some of the assays there may not have been sufficient $\mathrm{N}_{2}$-fixing cyanobacteria available in the initial water or in the inocula added. Although we added plankton from a variety of salinities, it was not always possible to find waters of intermediate salinities that could contain salt-tolerant $\mathrm{N}_{2}$-fixing species such as $N$. spumegina. It is also possible that appropriate organisms were present in the inocula, but that $\mathrm{N}_{2}$ fixation and (or) cyanobacterial growth was limited by factors other than P, such as trace elements (Howarth and Cole 1985; Evans and Prepas 1997), grazing (Marino et al. 2002), temperature (McQueen and Lean 1987; Marcarelli and Wurtsbaugh 2006), and light (Lewis and Levine 1984).

Light limitation of $\mathrm{N}_{2}$ fixation may be particularly important in Farmington Bay because light penetration is low as a result of eutrophic conditions. Therefore, photosynthesis by cyanobacteria may be light-limited, leading to a lack of energy to carry out the energetically expensive $\mathrm{N}_{2}$-fixation reaction (Lewis and Levine 1984). Some cyanobacterial taxa are adapted to low-light conditions. However, N. spumegina, at least in the Baltic Sea, prefer greater irradiances (45-155 $\mu \mathrm{mol}$ photons $\cdot \mathrm{s}^{-1} \cdot \mathrm{m}^{-2}$ ) than other cyanobacteria taxa (Lehtimäki et al. 1997). In Farmington Bay, this light intensity only penetrated, on average, to $0.5 \mathrm{~m}$ in the water column during the summer of 2005, suggesting that growth and $\mathrm{N}_{2}$ fixation of $N$. spumegina would have been light-limited in approximately $50 \%$ of the water column. However, on several occasions in 2005 we observed floating surface scums of $N$. spumegina, suggesting that this taxa may be able to outcompete other phytoplankton taxa for light, leading to a further growth advantage in Farmington Bay under low-salinity conditions.

Laboratory bioassays also have limitations, and field experiments are needed to unequivocally determine nutrient limitation in Farmington and Gilbert bays. Laboratory assays impart controlled conditions on the microbial communities, thus simplifying environmental variables and the interpretation of results. However, these assays also modify the environment so that experimental artifacts could occur. For example, we removed macrozooplankton (primarily brine shrimp) from the assays, but we did not remove microzooplankton. Consequently, grazing and nutrient recycling by zooplankton was not the same in the assays as in the lake, and this could alter the response to nutrients. Additionally, the jar experiments we used do not evaluate nutrient cycling between the benthic sediments and the water column, which can have important implications for the relative balance of $\mathrm{N}$ and $\mathrm{P}$ limitation in lakes (Levine and Schindler 1992). Consequently, to determine whether nutrient control is an appropriate management 
strategy for Farmington Bay, field experiments in limnocorrals or shore-based mesocosms should be used to study nutrient limitation under more natural conditions.

In conclusion, our laboratory experiments showed that under the high-salinity conditions typical in the Great Salt Lake, N limited phytoplankton growth, as has been suggested by previous researchers. However, when salinities were $<70 \mathrm{~g} \cdot \mathrm{L}^{-1}$, the $\mathrm{N}_{2}$-fixing $N$. spumegina can join the phytoplankton community, leading to high rates of $\mathrm{N}_{2}$ fixation and shifts of the phytoplankton community from $\mathrm{N}$ to $\mathrm{P}$ limitation. If nutrients were to be controlled to reduce eutrophication in Farmington Bay, the expected salinity levels would thus need to be incorporated into the decision process. This knowledge is particularly relevant as interest in improving water quality in the Great Salt Lake is currently growing, and potential management plans may examine scenarios such as breaching causeways to increase water, salt, and nutrient circulation. Interactions between these factors, including salinity and nutrient supply, will increase the difficulty associated with predicting the impacts of different management approaches. To that end, our experiments may help predict the interacting impacts of salinity and nutrient supply on eutrophic conditions in hypersaline systems, including the Great Salt Lake.

\section{Acknowledgements}

Invaluable field and lab assistance was provided by $\mathrm{D}$. Gross, P. Brown, K. Goodman, M. Kanaga, and L. Quantz. Funding for the project was provided by the Utah Department of Water Quality, the Central Davis Sewer District, and the Community/University Research Initiative (CURI) program at Utah State University. This paper was greatly improved by the comments of two anonymous reviewers.

\section{References}

Apte, S.K., Reddy, B.R., and Thomas, J. 1987. Relationship between sodium influx and salt tolerance of nitrogen-fixing cyanobacteria. Appl. Environ. Microbiol. 53(8): 1934-1939.

Brussaard, C.P.D., and Riegman, R. 1998. Influence of bacteria on phytoplankton cell mortality with phosphorus or nitrogen as the algal-growth-limiting nutrient. Aquat. Microb. Ecol. 14(3): 271-280.

Camacho, A., and de Wit, R. 2003. Effect of nitrogen and phosphorus additions on a benthic microbial mat from a hypersaline lake. Aquat. Microb. Ecol. 32(3): 261-273.

Carter, C.K. 1971. Some ecological considerations of the Farmington Bay estuary and adjacent Great Salt Lake Park. University of Utah, Salt Lake City, Utah.

Dubinin, A.V., Gerasimenko, L.M., and Zavarzin, G.A. 1992. Nitrogen-fixation by cyanobacterium Microcoleus chthonoplastes from hypersaline lagoons of Lake Sivash. Microbiology, 61(5): 593-597.

Elser, J.J., Marzolf, E.R., and Goldman, C.R. 1990. Phosphorus and nitrogen limitation in the freshwaters of North America: a review and critique of experimental enrichments. Can. J. Fish. Aquat. Sci. 47(7): 1468-1477.

Evans, J.C., and Prepas, E.E. 1997. Relative importance of iron and molybdenum in restricting phytoplankton biomass in high phosphorus saline lakes. Limnol. Oceanogr. 42(3): 461-472.

Felix, E.A., and Rushforth, S.R. 1979. The algal flora of the Great Salt Lake, Utah, U.S.A. Nova Hedwigia, 31: 163-195.
Fernandes, T.A., Iyer, V., and Apte, K. 1993. Differential responses of nitrogen-fixing cyanobacteria to salinity and osmotic stresses. Appl. Environ. Microbiol. 59(3): 899-904.

Flett, R.J., Hamilton, R.D., and Campbell, N.E.R. 1976. Aquatic acetylene-reduction techniques: solutions to several problems. Can. J. Microbiol. 22(1): 43-51.

Francoeur, S.N. 2001. Meta-analysis of lotic nutrient amendment experiments: detecting and quantifying subtle differences. J. North Am. Benthol. Soc. 20(3): 358-368.

Greenwood, J.L., and Rosemond, A.D. 2005. Periphyton response to long-term nutrient enrichment in a shaded headwater stream. Can. J. Fish. Aquat. Sci. 62(9): 2033-2045.

Herbst, D.B. 1998. Potential salinity limitations on nitrogen fixation in sediments from Mono Lake, California. Int. J. Salt Lake Res. 7: 261-274.

Herbst, D.B., and Blinn, D.W. 1998. Experimental mesocosm studies of salinity effects on the benthic algal community of a saline lake. J. Phycol. 34(5): 772-778.

Hillebrand, H., Durselen, C.D., Kirschtel, D., Pollingher, U., and Zohary, T. 1999. Biovolume calculation for pelagic and benthic microalgae. J. Phycol. 35(2): 403-424.

Howarth, R.W., and Cole, J.J. 1985. Molybdenum availability, nitrogen limitation, and phytoplankton growth in natural waters. Science (Washington, D.C.), 229(4714): 653-655.

Javor, B. 1989. Hypersaline environments. Springer-Verlag, Berlin, Germany.

Lehtimäki, J., Moisander, P., Sivonen, K., and Kononen, K. 1997. Growth, nitrogen fixation, and nodularin production by two Baltic Sea cyanobacteria. Appl. Environ. Microbiol. 63(5): 1647-1656.

Levine, S.N., and Schindler, D.W. 1992. Modification of the N-P ratio in lakes by in situ processes. Limnol. Oceanogr. 37(5): 917-935.

Lewis, W.M., Jr., and Levine, S.N. 1984. The light response of nitrogen fixation in Lake Valencia, Venezuela. Limnol. Oceanogr. 29(4): 894-900.

Mackay, M.A., Norton, R.S., and Borowitzka, L.J. 1983. Marine blue-green algae have a unique osmoregulatory system. Mar. Biol. 73: 301-307.

Marcarelli, A.M., and Wurtsbaugh, W.A. 2006. Temperature and nutrient supply interact to control nitrogen fixation in oligotrophic streams: an experimental examination. Limnol. Oceanogr. 51(5): 2278-2289.

Marino, R., Chan, F., Howarth, R.W., Pace, M., and Likens, G.E. 2002. Ecological and biogeochemical interactions constrain planktonic nitrogen fixation in estuaries. Ecosystems, 5(7): 719-725.

Mazur-Marzec, H., Zeglinska, L., and Plinski., M. 2005. The effect of salinity on the growth, toxin production, and morphology of Nodularia spumigena isolated from the Gulf of Gdansk, southern Baltic Sea. J. Appl. Phycol. 17(2): 171-179.

McQueen, D.J., and Lean, D.R.S. 1987. Influence of water temperature and nitrogen to phosphorus ratios on the dominance of bluegreen algae in Lake St. George, Ontario. Can. J. Fish. Aquat. Sci. 44(3): 598-604.

Mills, M.M., Ridame, C., Davey, M., La Roche, J., and Geider, R.J. 2004. Iron and phosphorus co-limit nitrogen fixation in the eastern tropical North Atlantic. Nature (London), 429(7039): 292-294.

Moisander, P.H., McClinton, E., and Paerl, H.W. 2002. Salinity effects on growth, photosynthetic parameters, and nitrogenase activity in estuarine planktonic cyanobacteria. Microb. Ecol. 43(4): 432-442.

Paerl, H.W. 1996. A comparison of cyanobacterial bloom dynamics in freshwater, estuarine and marine environments. Phycologia, 35(Suppl. 6): 25-35. 
Pinckney, J., Paerl, H.W., and Bebout, B.M. 1995. Salinity control of benthic microbial mat community production in a Bahamian hypersaline lagoon. J. Exp. Mar. Biol. Ecol. 187(2): 223-237.

Porcella, D.B., and Holman, J.A. 1972. Nutrients, algal growth, and culture of brine shrimp in the southern Great Salt Lake. In The Great Salt Lake and Utah's water resources. Edited by J.P. Riley. Utah Water Research Laboratory, Logan, Utah. pp. 142-155.

Postgate, J.R. 1998. The fundamentals of nitrogen fixation. 3rd ed. Cambridge University Press, Cambridge, UK.

Rushforth, S.R., and Felix, E.A. 1982. Biotic adjustments to changing salinities in the Great Salt Lake, Utah, USA. Microb. Ecol. 8:157-161.

SAS Institute Inc. 2000. SAS [computer software]. Version 8e. SAS Institute Inc., Cary, North Carolina.

Schindler, D. 1977. Evolution of phosphorus limitation in lakes. Science (Washington, D.C.), 195(4275): 260-262.

Stephens, D.W. 1990. Changes in lake levels, salinity and the biological community of Great Salt Lake (Utah, USA), 1847-1987. Hydrobiologia, 197(1): 139-146.

Stephens, D.W., and Gillespie, D.M. 1976. Phytoplankton production in the Great Salt Lake, Utah, and a laboratory study of algal response to enrichment. Limnol. Oceanogr. 21(1): 74-87.
Stewart, W.D.P., Fitzgerald, G.P., and Burris, H.R. 1967. In situ studies on $\mathrm{N}$-fixation using the acetylene reduction technique. Proc. Nat. Acad. Sci. U.S.A. 58(5): 2071-2078.

Vitousek, P.M., and Howarth, R.W. 1991. Nitrogen limitation on land and in the sea: how can it occur? Biogeochemistry, 13: 87-115.

Vitousek, P.M., Cassman, K., Cleveland, C., Crews, T., Field, C.B., Grimm, N.B., Howarth, R.W., Marino, R., Martinelli, L., Rastetter, E.B., and Sprent, J.I. 2002. Towards an ecological understanding of biological nitrogen fixation. Biogeochemistry, 57(1): $1-45$.

Welschmeyer, N.A. 1994. Fluorometric analysis of chlorophyll $a$ in the presence of chlorophyll $b$ and phaeopigments. Limnol. Oceanogr. 39(8): 1985-1992.

Wetzel, R.G., and Likens, G.E. 2000. Limnological analyses. 3rd ed. Springer, New York

Wurtsbaugh, W.A. 1988. Iron, molybdenum and phosphorus limitation of $\mathrm{N}_{2}$ fixation maintains nitrogen deficiency of plankton in the Great Salt Lake drainage (Utah, USA). Verh. Int. Ver. Limnol. 23: 121-130.

Zar, J.H. 1999. Biostatistical Analysis. 4th ed. Prentice Hall, Upper Saddle River, New Jersey.

\section{Appendix A}

Table A1. Responses of chlorophyll $a$ and nitrogen fixation to nutrient and salinity treatments on each sampling date in the four factorial bioassay experiments.

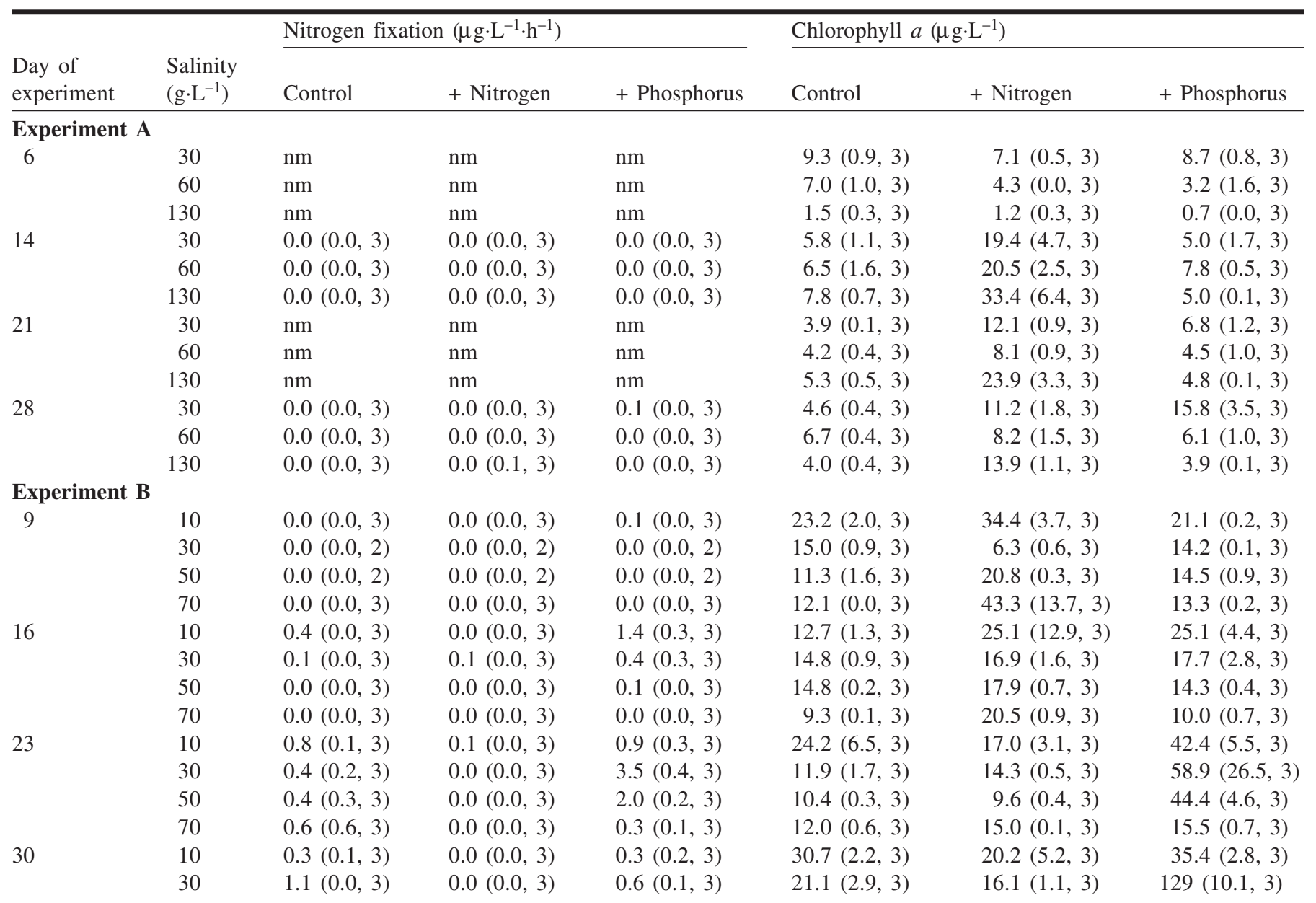


Table A1 (concluded).

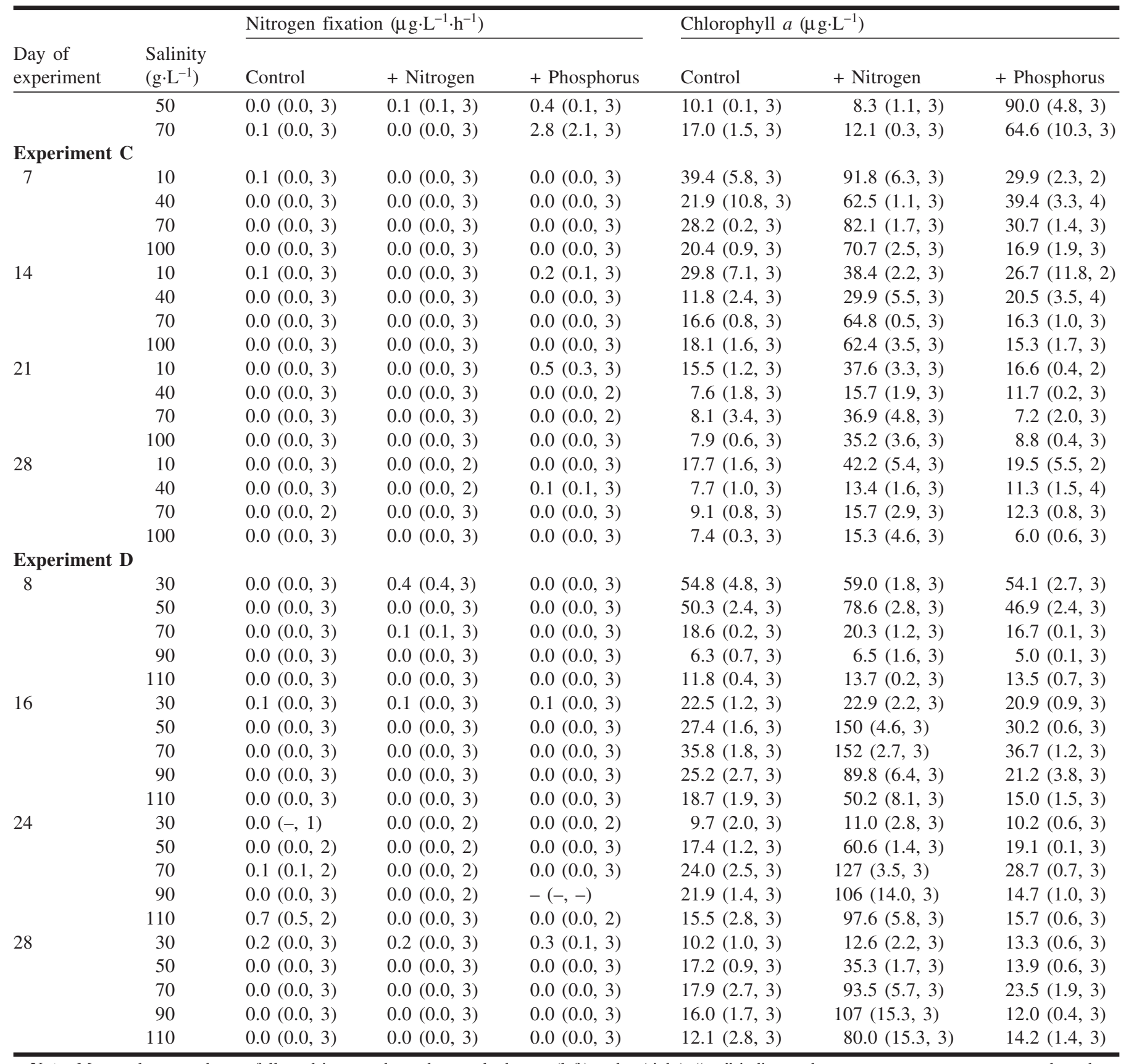

Note: Mean values are shown, followed in parentheses by standard error (left) and $n$ (right). "nm" indicates that a parameter was not measured on that experiment date; -, missing data or that standard error could not be calculated because of lack of replicates. 